\title{
Revisiting the Prevalence of Autism Spectrum Disorder among Omani Children A multicentre study
}

Watfa Al-Mamri, ${ }^{1}$ "Ahmed B. Idris, ${ }^{1}$ Samar Dakak, ${ }^{2}$ Muna Al-Shekaili, ${ }^{2}$ Zuwaina Al-Harthi, ${ }^{3}$ Asia M. Alnaamani, Fatma I. Alhinai, ${ }^{5}$ Saquib Jalees, ${ }^{1}$ Moza Al Hatmi, ${ }^{4}$ Mohamed A. El-Naggari, ${ }^{1}$ M. Mazharul Islam ${ }^{6}$

$$
\text { إعادة النظر في معدل إنتشار إضطراب طيف التوحد بين الأطفال العمانيين }
$$

وطفة المعمرية، أحمد بابكر إدريس، سمر دقاق، منى الشكيلي، زوينة الحارثية، أسيه النعمانية، فاطمة الهنائية، ثاقب جليس، موزة الحاتمية،

$$
\text { محمد النجاري، م.مظهر الإسلام }
$$

ABSTRACT: Objectives: This study aimed to provide an updated estimate of the prevalence of autism spectrum disorder (ASD) among Omani children. Methods: This retrospective descriptive study was conducted from December 2011 to December 2018. Data were retrieved from the three main autism diagnostic centres in Oman: Sultan Qaboos University Hospital, Royal Hospital and Al-Massarah Hospital. The ASD diagnosis was made by experienced clinicians based on the fifth edition of the Diagnostic and Statistical Manual of Mental Disorders (DSM-5). The overall population prevalence estimates per 10,000 children aged 0-14 years old in Oman were calculated using the denominator of the mid-period population data. Results: A total of 1,705 ASD cases were identified with the majority of cases being male (78.1\%). The overall prevalence rate of ASD was estimated at 20.35 per 10,000 children (95\% confidence interval: 19.39-21.32) between 2012-2018. Boys were found to have a 3.4-fold higher prevalence of ASD than girls (31.23/10,000 versus 9.07/10,000). Regionally, the majority of cases were found in the capital, Muscat, where the highest prevalence was 36.51 cases per 10,000 children. Conclusion: The prevalence of ASD among Omani children is 15-fold higher than estimates from 2011. This increase can be attributed to improvements in diagnostic services, increased awareness of ASD, better screening programmes and changes in diagnostic criteria. In addition, this increase in prevalence suggests a need for a registry of developmental disabilities and more extensive diagnostic and rehabilitation services in Oman.

Keywords: Autism Spectrum Disorder; Epidemiology; Prevalence; Oman.

الملخص: الههذف: هدفت هذه الدراسة إلى اعادة تقدير لمعدل انتشار إضطراب طيف التوحد بين الأطفال العمانيين. الطريقة: أجريت دراسة

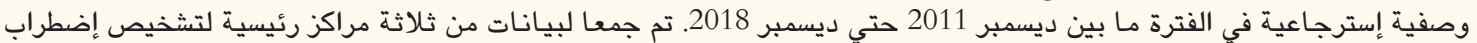

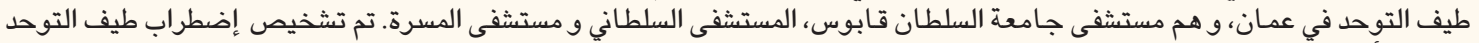



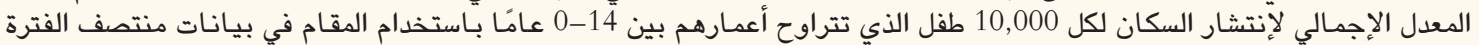

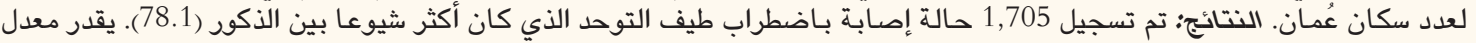

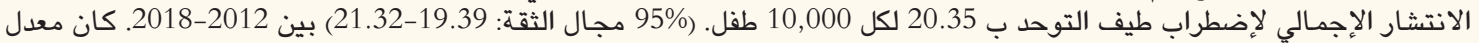

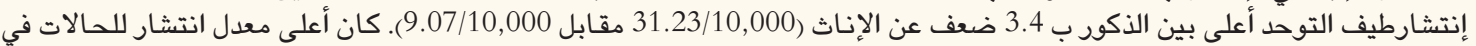

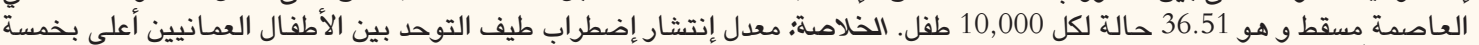

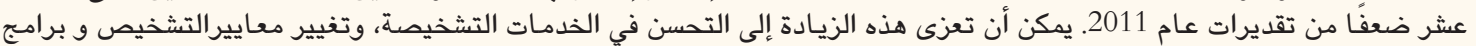

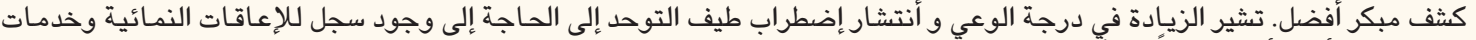

$$
\text { تشخيص وتأهيل أكثر شمولاً في عُمان. }
$$

$$
\text { الكلمات المفتاحية: إضطراب طيف التوحد؛ علم الأويئة؛ معدل انتشار؛ سلطنة عمان. }
$$

\section{ADVANCES IN KNOWLEDGE}

The prevalence of autism spectrum disorder among Omani children aged 0-14 years increased almost 15-fold from 2011 estimates.

\section{Application to Patient Care}

This study's findings indicate that a registry of developmental disabilities is needed and that diagnostic and rehabilitation services in Oman should be expanded. 
A UTISM SPECTRUM DISORDER (ASD) IS A neurodevelopmental disorder that is characterised by deficits in social communication and interaction as well as restricted repetitive patterns of behaviour, interests and activities. ${ }^{1}$ Although ASD is usually diagnosed after the age of three years, parental concerns commonly appear between the first and second years of life. Subtle characteristics are thought to be present even in infancy and include decreased social responsiveness, lack of empathy, absence of gestures, decreased pretend play and lack of attention to others. ${ }^{2}$ The gold standard tools for ASD diagnosis are based on behavioural observations that require the input of a clinician who is experienced in the diagnosis and treatment of ASD. ${ }^{1}$ The diagnostic criteria for ASD have been revised periodically, reflecting advances in research, practice and knowledge in this growing field. The Diagnostic and Statistical Manual of Mental Disorders fifth edition's (DSM-5) diagnostic criteria improve the specificity of the ASD diagnosis at the expense of sensitivity. ${ }^{3}$

In the past, ASD was thought to be a rare condition. Recently, the prevalence of ASD diagnoses have increased worldwide from approximately $0.0002-0.0006 \%$ of all individuals prior to the 1990s to current estimates of up to $2.6 \%{ }^{4-6}$ Globally, the median ASD prevalence is estimated to be 62 per $10,000 .{ }^{6}$ Some explanations for the increase in the observed prevalence of ASD include the development of better identification and screening methods, changes in diagnostic criteria, increased awareness among parents and clinicians, changes in the availability of services and in risk factors or aetiological causes. ${ }^{7,8}$

Based on available data, publications have reported that the prevalence of ASD ranges from 1.4 to 29 per 10,000 children among Arab Gulf countries. ${ }^{9,10}$ These prevalence estimates differ from the ASD prevalence rate estimated by the Centres for Disease Control and Prevention which reports that 1 in 59 children in the USA are affected. ${ }^{11}$ A South Korean study found a higher prevalence rate of ASD (about 1 in 38 children) than in Arab Gulf countries, which suggests that better screening methods may lead to substantially higher estimates of ASD's global prevalence in the future. ${ }^{12}$ Broadening the DSM-5's diagnostic criteria may play a role in differences in prevalence estimates as most publications from Arab Gulf countries are based on the DSM-4 criteria. ${ }^{13-15}$ However, the similar sociocultural factors and underdiagnosis of cases might be a commonality amongst Arab Gulf countries, including Oman.

The prevalence of ASD in the Omani population was estimated to be 1.4 per 10,000 children in 2011, which could most likely be an underestimation of the actual number of ASD cases. ${ }^{13}$ Since the developmental paediatric services in Oman are still in their infancy, underdiagnosis and under-reporting still place major constraints on estimations of ASD's true prevalence. . $^{13,16}$ Accurate prevalence estimates are essential for planning policy and service needs and identifying potential risk factors for ASD. The increase in ASD prevalence worldwide has raised concern among national governments and international agencies to take action in terms of advocacy and policy, research and service development. ${ }^{17,18}$ Therefore, this study aimed to examine the prevalence of ASD among Omani children in view of increasing awareness and developing better diagnostic services and broader diagnostic criteria.

\section{Methods}

This retrospective descriptive study was conducted between December 2011 and December 2018. Data were retrieved from the three main autism diagnostic centres in Oman: Sultan Qaboos University (SQU) Hospital, Royal Hospital and Al-Massarah Hospital. These three autism diagnostic centres are the only formal sources of diagnosing and recording ASD in Oman among the target population; thus, these three centres were likely to capture most of the diagnosed ASD cases in the country. Fulfilment of DSM- 5 criteria formed the basis of the ASD diagnoses. The identified subjects were reviewed thoroughly to ensure the absence of repetition, since different hospitals in Oman do not share electronic records. The target population consisted of all children below 14 years old who had been referred to a main diagnostic centre and formally diagnosed with ASD. Demographic data included age, gender and region/governorate of residence. In addition, the age at diagnosis was also recorded. Clinical information was obtained from the medical records at each study site.

As this study used retrospective data collected over seven years, period prevalence rates at national and subnational levels were used to reflect the proportion of patients with a particular disease or attribute at any time during the study's timeframe. Period prevalence rates were calculated using a mid-period population aged 0-14 years as the denominator, which corresponds to the mid-year population of the year 2015 from a previously published report on Oman population statistics by the National Centre for Statistical Information. ${ }^{19}$

A Chi-square test was used to compare groups. A $P$ value of less than 0.05 was considered statistically significant. Ethical approval was obtained from the Medical Research \& Ethics Committee of the College of Medicine \& Health Sciences, SQU and the Centre of Studies and Research, Research Committee, Ministry of Health, Oman in January 2017 (MREC \#1726; Unique Identification Code \#5820, respectively). 
Table 1: Distribution of children aged 0-14 years with autism spectrum disorder (ASD) and estimated prevalence of ASD in Oman $(\mathrm{N}=1,705)$

\begin{tabular}{|c|c|c|c|c|}
\hline Characteristic & n (\%) & $\begin{array}{l}\text { Mid-year } \\
\text { population }\end{array}$ & $\begin{array}{c}\text { Estimated } \\
\text { prevalence/ } \\
10,000 \\
\text { children } \\
(95 \% \mathrm{CI})\end{array}$ & $\begin{array}{c}P \\
\text { value }^{*}\end{array}$ \\
\hline \multicolumn{5}{|l|}{ Gender } \\
\hline Male & $\begin{array}{l}1,332 \\
(78.1)\end{array}$ & 426,450 & $\begin{array}{c}31.23 \\
(29.56-32.91)\end{array}$ & \multirow[b]{2}{*}{$<0.001$} \\
\hline Female & $\begin{array}{c}373 \\
(21.9)\end{array}$ & 411,205 & $\begin{array}{c}9.07 \\
(8.15-9.99)\end{array}$ & \\
\hline \multicolumn{5}{|l|}{ Age in years } \\
\hline $0-4$ & $\begin{array}{c}1,057 \\
(62)\end{array}$ & 348,419 & $\begin{array}{c}30.34 \\
(28.51-32.16)\end{array}$ & \multirow{3}{*}{$<0.001$} \\
\hline $5-9$ & $\begin{array}{c}550 \\
(32.3)\end{array}$ & 272,309 & $\begin{array}{c}20.2 \\
(18.51-21.88)\end{array}$ & \\
\hline $10-14$ & $\begin{array}{c}98 \\
(5.7)\end{array}$ & 216,927 & $\begin{array}{c}4.52 \\
(3.62-5.41)\end{array}$ & \\
\hline $\begin{array}{l}\text { Mean age in } \\
\text { years } \pm S D\end{array}$ & $4.8 \pm 2.4$ & - & - & - \\
\hline \multicolumn{5}{|c|}{ Region/governorate } \\
\hline Muscat & $\begin{array}{c}636 \\
(37.3)\end{array}$ & 174,198 & $\begin{array}{c}36.51 \\
(33.68-39.34)\end{array}$ & \multirow{12}{*}{$<0.001$} \\
\hline Dofar & $\begin{array}{c}64 \\
(3.8)\end{array}$ & 70,222 & $\begin{array}{c}9.11 \\
(6.88-11.35)\end{array}$ & \\
\hline Musandam & $\begin{array}{c}4 \\
(0.2)\end{array}$ & 9,373 & $\begin{array}{c}4.27 \\
(0.09-8.45)\end{array}$ & \\
\hline Al-Buraymi & $\begin{array}{c}12 \\
(0.7)\end{array}$ & 18,416 & $\begin{array}{c}6.52 \\
(2.83-10.2)\end{array}$ & \\
\hline Ad-Dakhliyah & $\begin{array}{c}231 \\
(13.5)\end{array}$ & 115,140 & $\begin{array}{c}20.06 \\
(17.48-22.65)\end{array}$ & \\
\hline $\begin{array}{l}\text { Al-Batinah } \\
\text { North }\end{array}$ & $\begin{array}{c}267 \\
(15.7)\end{array}$ & 165,423 & $\begin{array}{c}16.14 \\
(14.21-18.07)\end{array}$ & \\
\hline $\begin{array}{l}\text { Al-Batinah } \\
\text { South }\end{array}$ & $\begin{array}{c}182 \\
(10.7)\end{array}$ & 100,311 & $\begin{array}{c}18.14 \\
(15.51-20.78)\end{array}$ & \\
\hline $\begin{array}{l}\text { Ash-Sharqiyah } \\
\text { North }\end{array}$ & $\begin{array}{l}119 \\
(7)\end{array}$ & 58,244 & $\begin{array}{c}20.43 \\
(16.76-24.1)\end{array}$ & \\
\hline $\begin{array}{l}\text { Ash-Sharqiyah } \\
\text { South }\end{array}$ & $\begin{array}{l}139 \\
(8.2)\end{array}$ & 67,307 & $\begin{array}{c}20.65 \\
(17.22-24.08)\end{array}$ & \\
\hline Adh-Dhahirah & $\begin{array}{c}46 \\
(2.7)\end{array}$ & 50,873 & $\begin{array}{c}9.04 \\
(6.43-11.65)\end{array}$ & \\
\hline Al-Wusta & $\begin{array}{c}5 \\
(0.3)\end{array}$ & 8,148 & $\begin{array}{c}6.14 \\
(0.76-11.51)\end{array}$ & \\
\hline Total & $\begin{array}{l}1,705 \\
(100)\end{array}$ & 837,655 & $\begin{array}{c}20.35 \\
(19.39-21.32)\end{array}$ & \\
\hline
\end{tabular}

$C I=$ confidence interval; $S D=$ standard deviation. "Using Chi-square test.

\section{Results}

A total of 1,705 cases of ASD were identified during the study period out of a mid-interval population of 837,655 children aged $0-14$ years old. Most patients were below five years old (62\%) and predominantly male (78.1\%; $P<0.001)$. The mean age of children with

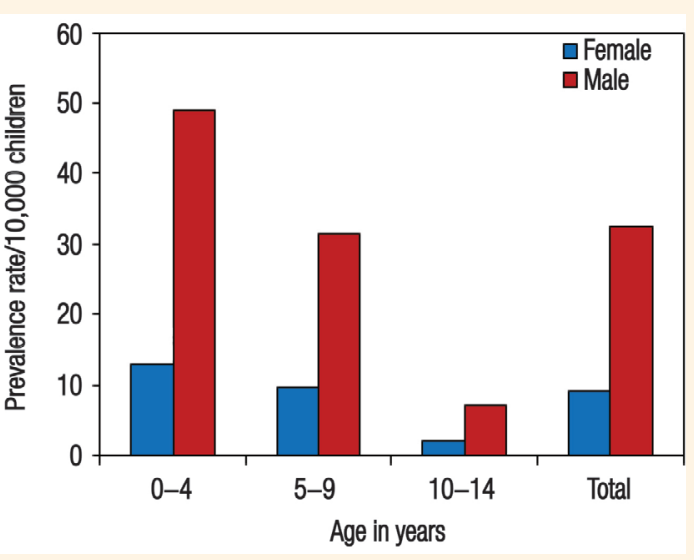

Figure 1: Estimated prevalence of autism spectrum disorder among the current study cohort classified by age and gender $(\mathrm{N}=1,705)$.

ASD was $4.8 \pm 2.4$ years. More than one-third (37.3\%) of the ASD cases were recorded in Muscat governorate, followed by Al-Batinah North governorate (15.7\%). The fewest cases were recorded in the Musandam and Al-Wusta governorates $(0.2 \%$ and $0.3 \%)$. This distribution of ASD cases is somewhat consistent with the distribution of the targeted population across Oman [Table 1].

The overall estimate of the prevalence of ASD in Oman was found to be 20.35 per 10,000 children (95\% confidence interval [CI]: 19.39-21.32). Males had a significantly higher (3.6-fold higher) prevalence of ASD than females (31.23/10,000 versus 9.07/10,000; $P<0.001)$ [Table 1]. This finding was true for all age groups [Figure 1]. The prevalence of diagnosed ASD cases showed an association with age. It was higher among children under five years old $(30.34 / 10,000)$ compared to children aged 5-9 years old $(20.2 / 10,000)$ and children aged $10-14$ years old $(4.52 / 10,000)$. The prevalence of ASD was found to vary significantly across Oman's administrative regions, with the majority of cases found in the capital, Muscat, where the prevalence was 36.51 cases per 10,000 children (95\% CI: 33.68-39.34). The prevalence in Al-Batinah North, being the second more populous region, was significantly lower (16.14/10,000; 95\% CI: 14.21-18.07). However, outside of Muscat, the prevalence was highest in Ash-Sharqiyah South (20.65/10,000; 95\% CI: 17.22-24.08) and lowest in Musandam (4.27/10,000; 95\% CI: 0.09-8.45) [Table 1].

\section{Discussion}

The prevalence of ASD among Omani children increased almost 15-fold since 2011 estimates. ${ }^{13}$ This finding could be attributed to an increase in the autism detection rate among the Omani population rather than a real environmental increment. Another factor 
that could contribute to this increase is the launch of the National Screening Programme for Autism and Other Developmental Disorders in early 2017. Although the programme has not reached its full potential yet, the collateral outcomes of awareness and media interest could have played a role. Although no published data are available for comparison, unpublished data from SQU estimated the prevalence by the end of 2015 to reach 8.5 cases per 10,000 children. ${ }^{20}$ Increasing community awareness plays a major role in detecting ASD within the general population. It has been reported that family members are the first to notice and report children's milestones. ${ }^{21}$ Although knowledge about autism in Omani school-teachers in mainstream schools has been described as low, it can be assumed that their awareness of ASD, like awareness in the general population, has improved in the last decade mostly due to media and increasing diagnostic facilities and governmental interests. ${ }^{22}$ Moreover, the increasing prevalence of ASD has been attributed to diagnostic substitution as the increment in the autism diagnosis has been accompanied by a decrease in labelling intellectual disability. ${ }^{23}$

The gender distribution found in the current study is comparable with international autism data. ${ }^{6,11,12}$ The vast majority of patients had a presenting age below four years old, which is in agreement with published studies on autism. ${ }^{24-26}$ The paucity of cases diagnosed in the older age group may be affected by the degree of the severity of the cases that were detected and referred from peripheral facilities. Coo et al. attributed similar findings to the possibility that mild-to-moderate cases were mixed in mainstream schools and special needs classes and, in these settings, were misclassified as intellectually disabled or as having learning difficulties rather than $\mathrm{ASD} .^{23}$

ASD is not limited by geographical or political boundaries unless it is linked to hidden genetic or environmental factors; hence, the differences in the prevalence of ASD among governorates may be due to an inconsistency in referral policies and accessibility to services. ${ }^{27,28}$ The findings of a relatively higher prevalence of ASD in Muscat and Ash-Sharqiyah regions highlight the importance of determining why these regions have a higher prevalence of ASD and develop region-specific approaches.

The current study's estimation of the prevalence was based on a hospital-based sample; thus, a major limitation may arise from the fact that many undiagnosed cases were not included in this cohort, leading to an underestimation of the true prevalence.

\section{Conclusion}

The prevalence of ASD among Omani children is estimated to be 20.35 per 10,000 children. The prevalence of ASD among Omani children is 15-fold greater than estimates from 2011. This rise can be attributed to improvements in the detection rate due to increasing awareness and screening programmes, better diagnostic services and changing diagnostic criteria. A registry of developmental disabilities should be established and diagnostic and rehabilitation services should be expanded.

\section{CONFLICT OF INTEREST}

The authors declare no conflicts of interest.

\section{FUNDING}

No funding was received for this study.

\section{References:}

1. American Psychiatric Association. Autism spectrum disorder. In: Diagnostic and Statistical Manual of Mental Disorders, 5th ed. Washington, DC: American Psychiatric Association, 2013. P. 50

2. Sigman M, Dijamco A, Gratier M, Rozga A. Early detection of core deficits in autism. Ment Retard Dev Disabil Res Rev 2004; 10:221-33. https://doi.org/10.1002/mrdd.20046.

3. McPartland JC, Reichow B, Volkmar FR. Sensitivity and specificity of proposed DSM-5 diagnostic criteria for autism spectrum disorder. J Am Acad Child Adolesc Psychiatry 2012; 51:368-83. https://doi.org/10.1016/j.jaac.2012.01.007

4. Fombonne E. Epidemiology of pervasive developmental disorders. Pediatr Res 2009; 65:591-8. https://doi.org/10.1203/ PDR.0b013e31819e7203.

5. Rice CE, Rosanoff M, Dawson G, Durkin MS, Croen LA, Singer A, et al. Evaluating changes in the prevalence of the autism spectrum disorders (ASDs). Public Health Rev 2012; 34:1-22. https://doi.org/10.1007/BF03391685.

6. Elsabbagh M, Divan G, Koh YJ, Kim YS, Kauchali S, Marcín C, et al. Global prevalence of autism and other pervasive developmental disorders. Autism Res 2012; 5:160-79. https://doi.org/10.1 002/aur.239.

7. King $M$, Bearman P. Diagnostic change and the increased prevalence of autism. Int J Epidemiol 2009; 38:1224-34. https://doi.org/10.1093/ije/dyp261.

8. Hansen SN, Schendel DE, Parner ET. Explaining the increase in the prevalence of autism spectrum disorders: The proportion attributable to changes in reporting practices. JAMA Pediatr 2015; 169:56-62. https://doi.org/10.1001/ jamapediatrics.2014.1893

9. Salhia HO, Al-Nasser LA, Taher LS, Al-Khathaami AM, El-Metwally AA. Systemic review of the epidemiology of autism in Arab Gulf countries. Neurosciences (Riyadh) 2014; 19:291-6.

10. Almandil NB, Alkuroud DN, AbdulAzeez S, AlSulaiman A, Elaissari A, Borgio JF. Environmental and genetic factors in autism spectrum disorders: Special emphasis on data from Arabian studies. Int J Environ Res Public Health 2019; 16:E658. https://doi.org/10.3390/ijerph16040658. 
11. Baio J, Wiggins L, Christensen DL, Maenner MJ, Daniels J, Warren Z, et al. Prevalence of autism spectrum disorder among children aged 8 years - Autism and developmental disabilities monitoring network, 11 sites, United States, 2014. MMWR Surveill Summ 2018; 67:1-23. https://doi.org/10.15585/mmwr. ss6706a1.

12. Kim YS, Leventhal BL, Koh YJ, Fombonne E, Laska E, Lim EC et al. Prevalence of autism spectrum disorders in a total population sample. Am J Psychiatry 2011; 168:904-12. https://doi. org/10.1176/appi.ajp.2011.10101532.

13. Al-Farsi YM, Al-Sharbati MM, Al-Farsi OA, Al-Shafaee MS, Brooks DR, Waly MI. Brief report: Prevalence of autistic spectrum disorders in the Sultanate of Oman. J Autism Dev Disord 2011; 41:821-5. https://doi.org/10.1007/s10803-010-1094-8.

14. Al-Salehi S, Al-Hifthy E, Ghaziuddin M. Autism in Saudi Arabia: Presentation, clinical correlates and comorbidity. Transcult Psychiatry 2009; 46:340-7. https://doi.org/10.1177/1363461509 105823.

15. Eapen V, Mabrouk A, Zoubeidi T, Yunis F. Prevalence of pervasive developmental disorders in preschool children in the UAE. J Trop Pediatr 2007; 53:202-5. https://doi.org/10.1093/ tropej/fml091.

16. Ouhtit A, Al-Farsi Y, Al-Sharbati M, Waly M, Gupta I, Al-Farsi O, et al. Underlying factors behind the low prevalence of autism spectrum disorders in Oman: Sociocultural perspective. Sultan Qaboos Univ Med J 2015; 15:e213-17.

17. Munir KM, Lavelle TA, Helm DT, Thompson D, Prestt J, Azeem MW. Autism: A global framework for action. From www.wish.org.qa/wp-content/uploads/2018/01/IMPJ4495_ WISH_Autism_Report_WEB.pdf Accessed: May 2019.

18. Dunlop AW, McGregor E, Marwick H, Ravet J, Robinson A, Rydzewska E, et al. Action on Autism Research in Scotland: An advanced international multidisciplinary, multi-agency research seminar series held between November 2013 and November 2014. From: https://strathprints.strath.ac.uk/59541/1/Dunlop_ etal_2016_Action_on_Autism_Research_in_Scotland.pdf Accessed: May 2019.

19. National Center for Statistics and Information. Sultanate of Oman. From: www.ncsi.gov.om Accessed: May 2019.
20. Al-Mamari W, Idris AB, Al-Jabri M, Abdelsattar A, Al-Hinai F, Al-Hatmi M, et al. A turning point for paediatric developmental services in Oman: Establishment of a national autism screening programme. Sultan Qaboos Univ Med J 2017; 17:e125-6. https://doi.org/10.18295/squmj.2016.17.01.026.

21. Wetherby AM, Brosnan-Maddox S, Peace V, Newton L. Validation of the Infant-Toddler Checklist as a broadband screener for autism spectrum disorders from 9 to 24 months of age. Autism 2008; 12:487-511. https://doi.org/10.1177/1362361308094501.

22. Al-Sharbati M, Al-Farsi YM, Ouhtit A, Waly MI, Al-Shafaee M, Al-Farsi O, et al. Awareness about autism among school teachers in Oman: A cross-sectional study. Autism 2015; 19:6-13. https://doi.org/10.1177/1362361313508025.

23. Coo H, Ouellette-Kuntz H, Lloyd JE, Kasmara L, Holden JJ, Lewis ME. Trends in autism prevalence: Diagnostic substitution revisited. J Autism Dev Disord 2008; 38:1036-46. https://doi. org/10.1007/s10803-007-0478-x.

24. Autism and Developmental Disabilities Monitoring Network Surveillance Year 2002 Principal Investigators, Centers for Disease Control and Prevention. Prevalence of autism spectrum disorders -- Autism and developmental disabilities monitoring network, 14 sites, United States, 2002. MMWR Surveill Summ 2007; 56:12-28.

25. Wiggins LD, Baio J, Rice C. Examination of the time between first evaluation and first autism spectrum diagnosis in a population-based sample. J Dev Behav Pediatr 2006; 27:S79-87.

26. Ouellette-Kuntz HM, Coo H, Lam M, Yu CT, Breitenbach MM, Hennessey PE, et al. Age at diagnosis of autism spectrum disorders in four regions of Canada. Can J Public Health 2009; 100:268-73. https://doi.org/10.1097/00004703-200604002-00005.

27. Hallmayer J, Cleveland S, Torres A, Phillips J, Cohen B, Torigoe $\mathrm{T}$, et al. Genetic heritability and shared environmental factors among twin pairs with autism. Arch Gen Psychiatry 2011; 68:1095-102. https://doi.org/10.1001/archgenpsy chiatry.2011.76.

28. Kinney D, Miller A, Crowley D, Huang E, Gerber E. Autism prevalence following prenatal exposure to hurricanes and tropical storms in Louisiana. J Autism Dev Disord 2008; 38:481-8. https://doi.org/10.1007/s10803-007-0414-0. 